\title{
Methanolic extract of white asparagus shoots activates TRAIL apoptotic death pathway in human cancer cells and inhibits colon carcinogenesis in a preclinical model
}

\author{
SOUAD BOUSSEROUEL ${ }^{1,2}$, JULIE LE GRANDOIS ${ }^{3}$, FRANCINE GOSSÉ $^{1,2}$, DALAL WERNER $^{3}$, \\ STEPHAN W. BARTH ${ }^{4}$, ERIC MARCHIONI ${ }^{5}$, JACQUES MARESCAUX ${ }^{2}$ and FRANCIS RAUL ${ }^{1,2}$ \\ ${ }^{1}$ University of Strasbourg, Unit EA 4438, Faculty of Medicine; ${ }^{2}$ Institut de Recherche contre les \\ Cancers de l'Appareil Digestif (IRCAD), Strasbourg; ${ }^{3}$ AERIAL, Illkirch, France; \\ ${ }^{4}$ Max Rubner Institute, Karlsruhe, Germany; ${ }^{5}$ University of Strasbourg, \\ Faculty of Pharmacy, IPHC, CNRS-UMR7178, Illkirch, France
}

Received March 21, 2013; Accepted May 3, 2013

DOI: 10.3892/ijo.2013.1976

\begin{abstract}
Shoots of white asparagus are a popular vegetable dish, known to be rich in many bioactive phytochemicals reported to possess antioxidant, and anti-inflammatory and antitumor activities. We evaluated the anticancer mechanisms of a methanolic extract of Asparagus officinalis L. shoots (Asp) on human colon carcinoma cells (SW480) and their derived metastatic cells (SW620), and Asp chemopreventive properties were also assessed in a model of colon carcinogenesis. SW480 and SW620 cell proliferation was inhibited by $80 \%$ after exposure to Asp $(80 \mu \mathrm{g} / \mathrm{ml})$. We demonstrated that Asp induced cell death through the activation of TRAIL DR4/DR5 death receptors leading to the activation of caspase- 8 and caspase-3 and to cell apoptosis. By specific blocking agents of DR4/DR5 receptors we were able to prevent Asp-triggered cell death confirming the key role of DR4/DR5 receptors. We found also that Asp $(80 \mu \mathrm{g} / \mathrm{ml})$ was able to potentiate the effects of the cytokine TRAIL on cell death even in the TRAIL-resistant metastatic SW620 cells. Colon carcinogenesis was initiated in Wistar rats by intraperitoneal injections of azoxymethane (AOM), once a week for two weeks. One week after (post-initiation) rats received daily Asp $(0.01 \%, 14 \mathrm{mg} / \mathrm{kg}$ body weight $)$ in drinking water. After 7 weeks of Asp-treatment the colon of rats exhibited a 50\% reduction of the number of preneoplastic lesions (aberrant crypt foci). In addition Asp induced inhibition of several pro-inflammatory mediators, in association with an increased expression of host-defense mediators. In the colonic mucosa of Asp-treated rats we also confirmed the
\end{abstract}

Correspondence to: Dr Francis Raul, IRCAD, 1 Place de l'Hôpital, 67091 Strasbourg-Cedex, France

E-mail: francis.raul@ircad.u-strasbg.fr

Key words: Asparagus officinalis, colorectal cancer, SW480 cells, SW620 cells, aberrant crypt foci, inflammation, caspases, death receptors pro-apoptotic effects observed in vitro including the activation of the TRAIL death-receptor signaling pathway. Taken together, our data highlight the chemopreventive effects of Asp on colon carcinogenesis and its ability to promote normal cellular homeostasis.

\section{Introduction}

Colorectal carcinogenesis is generally a slow process spanning decades from cancer initiation to diagnosis. Thus, this time span provides considerable opportunity to focus on the discovery and identification of dietary agents and drugs that might prevent or inhibit tumor development (1). Since about one-third of the overall risk of cancer in human may be related to diet, a large number of dietary compounds have been tested to determine their potential chemopreventive properties in various experimental cancer models (2-4). Many vegetables and their bioactive compounds exhibit strong chemopreventive ability against several neoplasms, including colorectal cancer, as evidenced by epidemiological and experimental studies (5-7). Asparagus officinalis L. is a popular vegetable dish consumed in most part of the world. Asparagus is rich in many bioactive phytochemicals such as steroidal saponins (8-10), flavonoids $(11,12)$, dietary fibre (13) and oligosaccharides (14). Several asparagus constituents have been reported to possess antioxidant $(12,15)$ anti-inflammatory (16), antitumor (10), hypolipidaemic (17) and antifungal (18) activities. However, there is a lack of information regarding the antitumor properties of asparagus constituents especially on colorectal cancer.

The aim of the present study was to gain more insight into the anti-proliferative mechanisms of a methanolic extract of white Asparagus officinalis shoots on human colon carcinoma cells, and to evaluate its anti-carcinogenic potential in a preclinical rat model of colon carcinogenesis. Until now, activation of cancer cell death by constituents isolated from asparagus was only shown for human promyelocytic leukemia cells (HL-60) (19), liver hepatocellular cells (HepG2) (20) and a reduction of cell viability associated with elevated 
expression of some apoptotic markers in colon carcinoma HCT116 cells (21).

In order to address both primary and metastatic colorectal cancer cells, we used the human colon cancer SW480 cells and their derived metastatic SW620 cells as a model for colorectal cancer progression. The SW480 cell line is isolated from a primary human colon adenocarcinoma, and the SW620 cell line is derived from the primary tumor but isolated from a mesenteric lymph node metastasis of the same patient. These two cell lines have been validated as an in vitro model of colon cancer progression from a primary tumor to its metastatic spreading (22).

Anticancer activity of asparagus shoots has not been demonstrated in vivo. In order to evaluate the chemopreventive effects of asparagus shoot extract we used the well-known azoxymethane (AOM)-induced colon cancer model in rat (23-25). In this model, one of the earliest recognizable precancerous lesions is the appearance of hyper proliferative aberrant crypt foci (ACF) about 5 weeks after cancer initiation by AOM (26-28). These foci are putative precancerous lesions that indicate the initiation of a carcinogenic process. ACF have been used as surrogate biomarkers to screen numerous potential chemopreventive agents (26), also highlighting the importance of the rat-AOM model in the screening for new drugs designed for preventive and/or therapeutic activity against colorectal cancer. Here, we extended these investigations in order to determine the effects of an oral administration of a methanolic extract of white Asparagus officinalis L. shoots (Asp) on the development of AOM-induced ACF formation, and on the expression of several biomarkers involved in the inflammatory and apoptotic responses in the early post-initiation phases of colon carcinogenesis.

\section{Materials and methods}

Plant material. The shoots of Asparagus officinalis L. (var. Gijnlim) were provided by a local asparagus producer (Spargelhof Böser, Bruchsal, Germany). The crushed shoots (about $13 \mathrm{~kg}$ ) were freeze-dried (912 g after freeze-drying) and then extracted successively with $\mathrm{CH}_{2} \mathrm{Cl}_{2}$ and $\mathrm{CH}_{3} \mathrm{OH}$. Extraction was performed three times with $\mathrm{CH}_{2} \mathrm{Cl}_{2}(150 \mathrm{ml}$ for $15 \mathrm{~g}$ ) for $6 \mathrm{~h}$ (about 25-30 extraction cycles) using a Soxhlet apparatus (150 ml, Behr, Germany). The extracts were combined and evaporated under vacuum at $40^{\circ} \mathrm{C}$. The asparagus residue was then extracted three times by maceration under stirring for $2 \mathrm{~h}$ with $\mathrm{CH}_{3} \mathrm{OH}(150 \mathrm{ml}$ for $15 \mathrm{~g})$. All three methanolic extracts were then combined and concentrated under vacuum at $40^{\circ} \mathrm{C}$. The crude methanolic extract (PE) was freeze-dried and subsequently purified on a $\mathrm{C} 18$ Sep-Pak cartridge (10 g, 35 cc, Waters, Dachstein, France). About $2 \mathrm{~g}$ of freeze-dried PE was dissolved in $10 \mathrm{ml}$ water and loaded onto the cartridge, previously activated using $50 \mathrm{ml}$ $\mathrm{CH}_{3} \mathrm{OH}+0.1 \%$ formic acid, then conditioned with $50 \mathrm{ml}$ $\mathrm{H}_{2} \mathrm{O}+1 \%$ formic acid. The washing step was performed using $75 \mathrm{ml}$ of $\mathrm{H}_{2} \mathrm{O}+1 \%$ formic acid to remove sugars and organic acids. Fraction of interest (Asp) was then eluted from the cartridge using $75 \mathrm{ml}$ of $\mathrm{CH}_{3} \mathrm{OH}+0.1 \%$ formic acid, concentrated under vacuum and freeze-dried.

Cell culture. SW480 and SW620 cells were obtained from the European Collection of Animals Cell Culture (Salisbury,
UK). They were maintained in Dulbecco's modified Eagle's medium (DMEM) containing $25 \mathrm{mM}$ glucose and supplemented with $10 \%$ heat-inactivated $\left(56^{\circ} \mathrm{C}\right)$ horse serum, $100 \mathrm{U} /$ $\mathrm{ml}$ penicillin, $100 \mu \mathrm{g} / \mathrm{ml}$ streptomycin and $1 \%$ non-essential amino acids (Invitrogen Corp., Cergy Pontoise, France) and kept at $37^{\circ} \mathrm{C}$ in a humidified atmosphere with $5 \% \mathrm{CO}_{2}$. For experiments, after trypsinization $(0.5 \%$ trypsin $/ 2.6 \mathrm{mM}$ ethylenediamine tetra-acetic acid), cells were seeded at $1 \times 10^{6}$ cells in culture dishes $(100 \mathrm{~mm}$ internal diameter $)$ or at $2 \times 10^{5}$ cells in culture dishes ( $25 \mathrm{~mm}$ internal diameter). The culture medium was DMEM supplemented with $3 \%$ heat-inactivated horse serum, $100 \mathrm{U} / \mathrm{ml}$ penicillin, $100 \mu \mathrm{g} / \mathrm{ml}$ streptomycin, $5 \mu \mathrm{g} / \mathrm{ml}$ transferrin, $5 \mathrm{ng} / \mathrm{ml}$ selenium, $10 \mu \mathrm{g} / \mathrm{ml}$ insulin and $1 \%$ non-essential amino acids (Invitrogen Corp.).

Cell growth rate. Cells were exposed $24 \mathrm{~h}$ after seeding to different concentrations of Asp varying from 0 to $80 \mu \mathrm{g} / \mathrm{ml}$. The final concentration of DMSO in the culture medium was $0.1 \%$. Control cells were treated with DMSO 0.1\%. Culture medium was replaced every $48 \mathrm{~h}$. At different time points, cell culture was stopped by the addition of trichloroacetic acid $(50 \% \mathrm{v} / \mathrm{v})$, and cell proteins were determined by staining with $200 \mu \mathrm{l}$ Sulforhodamine B (0.4\% w/v) (Sigma-Aldrich, Saint Quentin Fallavier, France). The relationship between cell number (protein content per well) and absorbance is linear from 0 to $2 \times 10^{5}$ cells/well.

Cell death analysis by flow cytometry and treatments. Cells $\left(2 \times 10^{5}\right)$ were seeded on culture dishes $(25 \mathrm{~mm}$ diameter) and were incubated with TRAIL (50 ng/ml) (Alexis Biochemicals, Lausen, Switzerland) or with Asp $(80 \mu \mathrm{g} / \mathrm{ml})$ or with a combination TRAIL + Asp $(80 \mu \mathrm{g} / \mathrm{ml})$. Cells were centrifuged and fixed with $1 \mathrm{ml}$ methanol: PBS (9:1 v/v), washed twice in PBS and re-suspended in $200 \mu \mathrm{l}$ PBS containing $0.25 \mu \mathrm{g} / \mathrm{ml}$ RNase A and $0,1 \mathrm{mg} / \mathrm{ml}$ propidium iodide (Sigma-Aldrich). After incubation in the dark at $37^{\circ} \mathrm{C}$ for $30 \mathrm{~min}$, the fluorescence of 10,000 cells was analyzed by flow cytometry and CellQuest software (FACScan, BD Biosciences, Erembodegem, Belgium).

For caspase inhibition, cells were pre-treated with the specific pan-caspase-inhibitor Z-VAD-FMK at $20 \mu \mathrm{M}$ (MBL International Corporation, Japan) for $1 \mathrm{~h} 30 \mathrm{~min}$ before treatment with ASP. Cells were harvested after $24 \mathrm{~h}$ and processed as described above.

For the study on the role of DR4 and DR5 death receptors, Human recombinant DR4/Fc and DR5/Fc chimera proteins were purchased from R\&D Systems (Lille, France) and used at $100 \mathrm{ng} / \mathrm{ml}$ with a pre-treatment time of $30 \mathrm{~min}$. Cells were harvested after $24 \mathrm{~h}$ and processed as described above.

Measurement of caspase-3 and caspase-8 activities. Caspase activity was measured by colorimetric assay kits (Sigma-Aldrich) according to the manufacturer's instructions. Briefly, $20 \mu \mathrm{l}$ of cell or tissue lysates were added to a buffer containing a p-nitroaniline (pNA)-conjugated substrate for caspase-3 (Ac-DEVD-pNA) or -8 (Ac-IETD-pNA) to a total reaction volume of $100 \mu \mathrm{l}$. Incubation was carried at $37^{\circ} \mathrm{C}$. The concentration of the released pNA was calculated from the absorbance values at $405 \mathrm{~nm}$ and the calibration curve of defined pNA solutions. Data were adjusted according to the protein content. 
Expression of TRAIL death receptors DR4 and DR5. Cells were treated with Asp $(80 \mu \mathrm{g} / \mathrm{ml})$ and harvested by trypsinization at 24 and $48 \mathrm{~h}$. Cell pellets were washed with PBS and incubated with FITC-conjugated mouse anti-human TRAIL receptors DR4 and DR5 (Alexis Biochemicals), or FITC-conjugated mouse IgG1 monoclonal isotype control antibody (BD Biosciences) for $30 \mathrm{~min}$ at $4^{\circ} \mathrm{C}$ in the dark. After washing with PBS, cells were re-suspended in PBS and the fluorescence $(515 \mathrm{~nm})$ of 10.000 events per sample were analyzed by FACScan and CellQuest Software (BD Biosciences).

Real-time quantitative reverse-transcriptase polymerase chain reaction analysis. Total RNA was isolated, using the RNeasy Plus mini kit (Qiagen, Austin, TX, USA), from SW480 and SW620 cells after 24 and $48 \mathrm{~h}$ treatment with Asp, or from the scraped proximal colon mucosa of $\mathrm{NaCl}$-injected rats, AOM-injected rats and of Asp-treated AOM-injected rats. The High Capacity cDNA Reverse Transcription kit (Applied Biosystems, Foster City, CA, USA) was used for cDNA synthesis as recommended by the supplier. RT-PCR was performed by using ABI TaqMan gene expression assays for rats: $M M P-7, M M P-9$ (assay ID: Rn00563467; Rn00579162), IL1 $\beta, T N F-\alpha$ (assay ID: Rn99999009; Rn99999017), $D E F-5, L C N 2$ (RN01478512; RN00590612) and Bcl-2, Bax, (assay ID: Rn99999125; Rn02532082), FAS (CD95), FASL, DR5, TRAIL (RN00685720; RN00563754; RN01753393; RN00686175); and for human SW40 and SW620 cells: DR4 and DR5 (assay ID: Hs00269492 and Hs00366272) according to the manufacturer's instructions. All samples were run in triplicate in $25 \mu \mathrm{l}$ reaction volume. Quantitative real-time RT-PCR was performed by using TaqMan Universal PCR Master mix (Applied Biosystems) and the ABI Prism 7500 Sequence Detection System (Sequence detector; Applied Biosystems) in triplicate wells. The data were analyzed by a comparative threshold cycle (Ct) method. CT values were calculated using the 7500 SDS software (Applied Biosystems). The corresponding mRNA level from colonic mucosa of $\mathrm{NaCl}$-injected control rats was used as an external reference. The level of $\beta$-actin mRNA (assay ID: Rn00667869 or assay ID: Hs99999903) of each sample was used as an internal reference to normalize the data. For the in vivo experiments, the fold-changes of each mRNA (mRNA relative expression) were expressed relative to the mean value of the corresponding mRNA found in the mucosa of the $\mathrm{NaCl}$-injected control rats and was calculated using the $2^{\Delta \Delta C T}$ method (29).

Animals and treatments. All animal experiments were performed in accordance with the institutional guidelines of the French Ethics Committee (authorization no. A67-480, French Ministry of Agriculture). Male Wistar rats $(\mathrm{n}=24)$ obtained from C.E.R. Janvier (Le Genest St Isle, France) and weighing $300 \mathrm{~g}$ were housed under standardized conditions $\left(22^{\circ} \mathrm{C}, 60 \%\right.$ relative humidity, $12 \mathrm{~h}$ light $/ 12 \mathrm{~h}$ dark cycle, 20 air changes/h) and fed a standard chow with free access to drinking water. Sixteen rats received intra-peritoneal injections of azoxymethane (AOM) (Sigma-Aldrich), at a concentration of $15 \mathrm{mg} / \mathrm{kg}$ body weight, once a week for 2 weeks. One week after the last injection of AOM (post- initiation), rats were randomly separated into two groups. One group $(\mathrm{n}=8)$ received daily at $5 \mathrm{pm}$ a solution of $0.01 \%$ Asp $(14 \mathrm{mg} / \mathrm{kg}$ body weight) in drinking water. The AOM-treated control rats $(n=8)$ received drinking water. One group of rats $(\mathrm{n}=8)$ injected with $0.9 \% \mathrm{NaCl}$ (saline) once a week for 2 weeks receiving drinking water was used as reference. Rats consumed daily about $40 \mathrm{ml}$ of the drinking fluid during the whole experimental period. All animals were sacrificed 7 weeks after AOM or saline injection.

Assessment of aberrant crypts in the colon. The determination of hyperproliferative aberrant crypts was performed on a segment of $6 \mathrm{~cm}$ in length, corresponding to the distal part of the colon. The segment was washed with physiological saline, cut open, pinned out flat and fixed in $10 \%$ buffered formalin. The colon was stained with $0.2 \%$ methylene blue for $5 \mathrm{~min}$, rinsed in Krebs-Ringer buffer, placed onto a glass slide and examined microscopically using a low-power objective (x5) to assess hyperproliferative crypts and aberrant crypt foci (ACF). The criteria for the identification of hyperproliferative aberrant crypts were: i) increased size; ii) thicker epithelial cell lining; and iii) increased pericryptal zone relative to normal crypts. Mucosal samples of the distal colon of NaCl-injected rats, AOM-injected control rats and Asp-treated AOM-injected rats were scraped off with a glass slide and immediately frozen in liquid nitrogen for biological assays.

Western blot analyses of protein expression. Mucosal samples were homogenized in a RIPA lysis buffer composed of $150 \mathrm{mM} \mathrm{NaCl}, 50 \mathrm{mM}$ Tris (pH 8.0), $5 \mathrm{mM}$ EDTA, using a polytron homogenizer. After ultra-centrifugation for $30 \mathrm{~min}$ at $10,000 \mathrm{x} \mathrm{g}$ at $4^{\circ} \mathrm{C}$, the protein content was measured by the Lowry method. Equal amounts of total protein were separated by $15 \%$ sodium dodecyl sulfate (SDS)-polyacrylamide gel electrophoresis for $2 \mathrm{~h} 30 \mathrm{~min}$ at $65 \mathrm{~V}$. Proteins were then transferred to a nitrocellulose membrane (Bio-Rad Laboratories, Marnes-la-Coquette, France). The membrane was blocked with a solution containing bovine serum albumin (BSA) 3\%, Tween-20 0.1\%, Tris-HCl $10 \mathrm{mM}$ (pH 7.5), and $0.1 \% \mathrm{NaCl}$, for $1 \mathrm{~h}$ and, after stripping for $30 \mathrm{~min}$ at $50^{\circ} \mathrm{C}$ with a buffer containing $100 \mathrm{mM} \beta$-mercaptoethanol, $2 \%$ SDS and $62 \mathrm{mM}$ Tris- $\mathrm{HCl}\left(\mathrm{pH} \mathrm{6.7)}\right.$, was incubated overnight at $4^{\circ} \mathrm{C}$ with one of the following primary monoclonal antibodies: rabbit anti-rat DR5 at 1:500 (BD Biosciences, Erembodegem, Belgium), goat anti-rat LCN2 at 1:5,000 (Calbiochem, Merck Biosciences), rabbit anti-rat MMP-7 at 1:500 (Santa Cruz Biotechnology, Santa Cruz, USA) or mouse anti-rat $\beta$-actin at 1:2,000 (Chemicon International, Hampshire, UK). The membranes were washed and incubated with $0.02 \mu \mathrm{g} / \mathrm{ml}$ horseradish peroxidase (HRP)-conjugated goat anti-rabbit IgG (Calbiochem, Merck Biosciences) or donkey anti-goat IgG (Calbiochem, Merck Biosciences) for $1 \mathrm{~h}$ and visualized using the Super Signal West Pico Chemiluminescent Substrate System (Pierce).

Statistical analysis. Data are reported as the mean \pm SE. Statistical differences between control and treated groups were evaluated using the Student's t-test or the Student-Newman-Keuls multiple comparison test. 

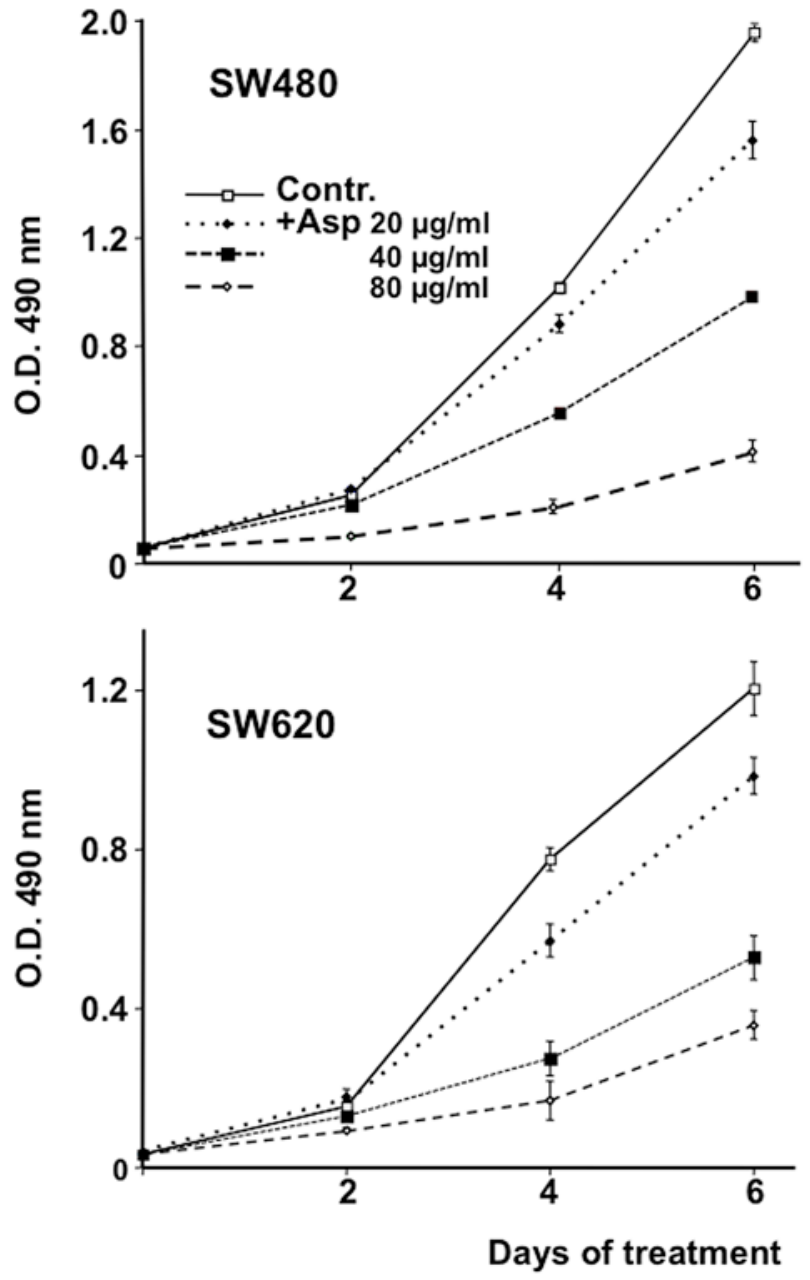

Figure 1. Effect of Asp on SW480 and SW620 cell growth. Cells were exposed to different concentrations of Asp varying from 0 to $80 \mu \mathrm{g} / \mathrm{ml}$ starting $24 \mathrm{~h}$ after seeding. Asp was diluted in DMSO and the final concentration of DMSO did not exceed $0.1 \%$ in the culture medium. Control cells were treated with $0.1 \%$ DMSO. Data are the mean of three separate experiments.

\section{Results}

Effect of Asp on SW480 and SW620 cell growth. SW480 and SW620 cells were exposed for 2 to 6 days to a methanolic extract of Asparagus officinalis L. shoots (Asp) at concentrations varying from 20 to $80 \mu \mathrm{g} / \mathrm{ml}$. As shown in Fig. 1 cell growth inhibition was observed in a dose-dependent manner. After 4 days of treatment, Asp at a concentration of $80 \mu \mathrm{g} / \mathrm{ml}$ induced an $80 \%$ inhibition of cell growth in both cell lines.

Propidium iodide allows the study of cell distribution in each phase of the cell cycle by measurement of cellular DNA content. After induction of cell death, DNA is degraded leading to formation of hypodiploid cells. These cells are detected by flow cytometric analysis in the sub-G0/G1 region (30). The amount of hypodiploid cells was measured 24 and $48 \mathrm{~h}$ after treatment with Asp. As shown in Fig. 2, the sub-G0/G1 population of SW480 and SW620 cells increased progressively with time after treatment with Asp. The percentage of hypodiploid cells was always higher in SW620 cells when compared to SW480 cells, indicating a higher sensibility of the metastatic cells to Asp treatment.
Effects of Asp on the expression of apoptotic-related proteins. To further explore the underlying mechanisms induced by Asp, we measured the expression of death receptor DR4 and DR5 of the TRAIL signaling pathway that tightly control apoptosis progression. We determined the protein and mRNA expression levels of DR4 and DR5 by flow cytometry and qRT-PCR. After treatment with Asp for 24 and 48 h, we observed upregulation of DR4 and DR5 protein expression at the cell surface of SW480 and SW620 cells (Fig. 3). The upregulation of DR4 and DR5 was higher in the metastatic SW620 cells when compared to the SW480 cells. Similarly, in Asp-treated SW480 cells, the amount of DR4 and DR5 transcripts remained significantly lower when compared with the level detected in SW620 cells (Fig. 4A). The DR4 and DR5 mRNA level increased significantly in SW620 cells in a time-dependent manner, respectively, by about 2-fold at $24 \mathrm{~h}$ and by 4 -fold at $48 \mathrm{~h}$ compared with untreated control cells.

To demonstrate whether the observed Asp-induced cell death was mediated through the TRAIL DR4/DR5 death receptors, we used human recombinant DR4/Fc and DR5/Fc chimerical protein exhibiting a dominant-negative effect by blocking the endogenous receptors. As shown in Fig. 4B, the addition of DR4/Fc and DR5/Fc chimera (@DR4/DR5) led to a significant reduction of cell death in Asp-treated SW480 and SW620 cells.

Caspase- 8 and caspase- 3 activities. In most cases, activation of the TRAIL death receptor pathway targets the caspase activation cascade (31). We showed that the increased expression of DR4/DR4 death receptors triggered by Asp was associated with caspase- 8 (Fig. 5A) and caspase-3 (Fig. 5B) activation in both SW480 and SW620 cells. To further assess the role played by caspases in the cell death induced by Asp, we used the pan-caspase-inhibitor Z-VAD-FMK, and measured cell death after 24 and $48 \mathrm{~h}$ (Fig. 5C). When SW480 and SW620 cells were treated with the pan-caspase inhibitor, Asp-induced cell death was blocked.

Sensitization of Asp-treated cancer cells to TRAIL. The human colon cancer cell line SW480 is known to be TRAIL-sensitive while its derived metastatic cell line SW620 is TRAIL-resistant (32). Here, we investigated the effects of exogenous recombinant human TRAIL alone, or in combination with Asp. As shown in Fig. 6, TRAIL as a single drug exhibited only a week activity on SW480 cells and remained ineffective on SW620 cells. However, TRAIL potentiated the effects of Asp on both SW480 and SW620 cell death enhancing significantly the effects of Asp on cell death in both cell lines ( $95 \%$ of cell death after $48 \mathrm{~h}$ of treatment).

Asp inhibits the development of preneoplastic lesions in the colon of rats. Based on our results showing strong anticancer effects of Asp on colon adenocarcinoma SW480 and metastatic SW620 cells in culture, we examined the efficacy of Asp in a rat model of colon carcinogenesis using azoxymethane (AOM)-initiated colon cancer. Colon carcinogenesis was induced in rats by intra-peritoneal injections of the chemical carcinogen AOM once a week for 2 weeks. Starting one week after the last injection rats received $0.01 \%$ of daily freshly prepared Asp (14 mg/kg body weight) in their drinking fluid. 


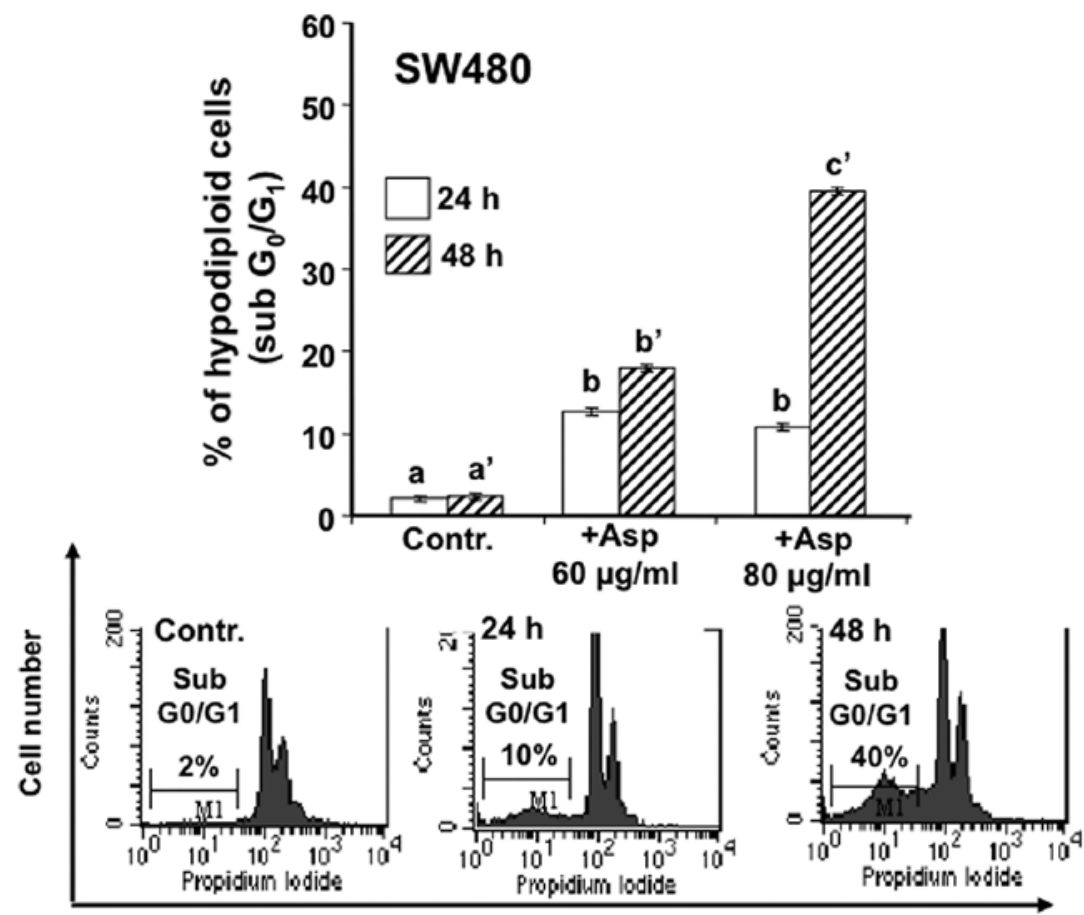

Fluorescence intensity
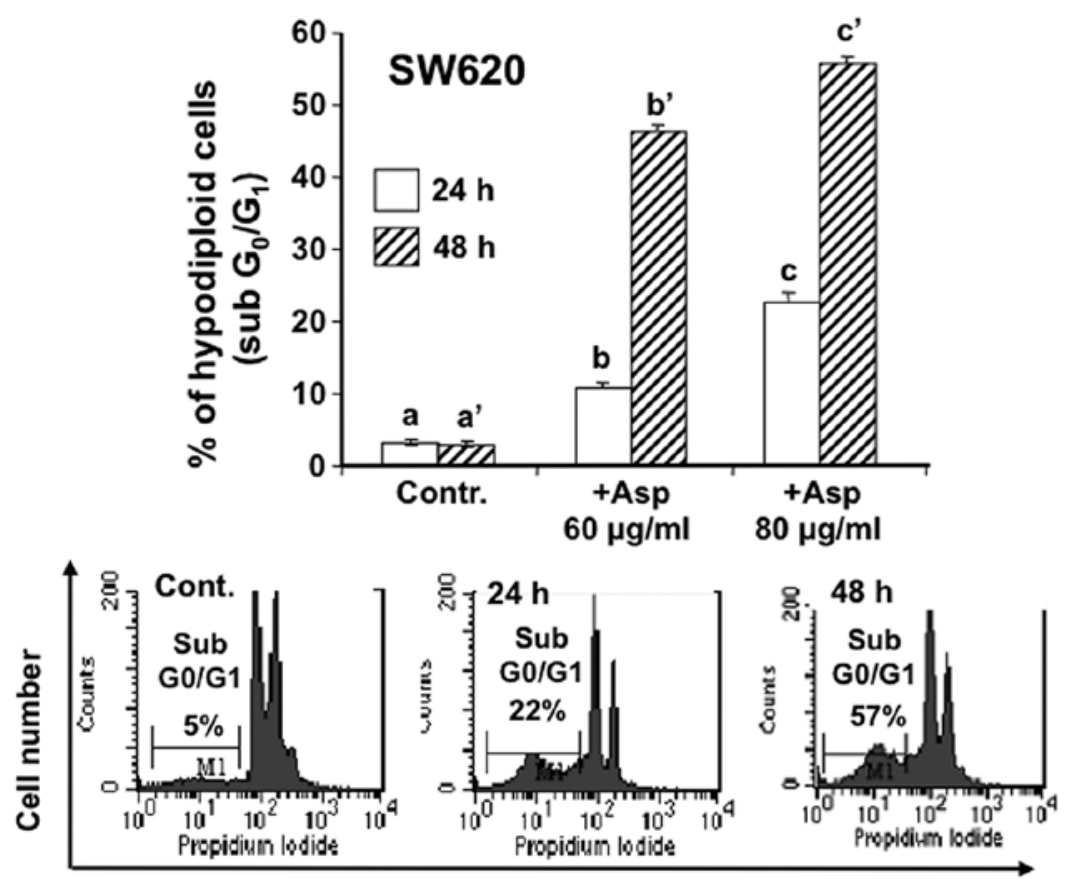

Fluorescence intensity

Figure 2. Effects of Asp on SW480 and SW620 cell death. Cells were treated with 60 or $80 \mu \mathrm{g} / \mathrm{ml}$ Asp for 24 and $48 \mathrm{~h}$. At each time point, SW480 and SW620 cells were harvested and stained with propidium iodide for the measurement of hypodiploid bodies and analyzed by flow cytometry as detailed in Materials and methods. For each cell line representative FACS histograms are shown in $48 \mathrm{~h}$ controls, and in SW480 and SW620 cells treated for 24 and $48 \mathrm{~h}$ with $80 \mu \mathrm{g} / \mathrm{ml} \mathrm{Asp}$. The columns are the mean value of hypodiploid cells present in the sub G0/G1 region. At 24 or $48 \mathrm{~h}$ each column not sharing the same superscript letter differ significantly, $\mathrm{P}<0.05$.

After 7 weeks of intervention, the colon of $\mathrm{NaCl}$-injected rats exhibited no preneoplastic lesions (i.e., aberrant crypts or $\mathrm{ACF}$ ) in contrast to the colonic mucosa of AOM-injected rats that always exhibited preneoplastic lesions. AOM-injected rats receiving Asp showed a 2 -fold reduction of preneoplastic lesions when compared with the AOM control group (Fig. 7).
Modulation by Asp of inflammatory and host-defense gene expression in colonic mucosa. To gain more insight into the mechanisms underlying the in vivo antitumor efficacy of Asp, mucosa tissues were analyzed by quantitative real-time RT-PCR for the differential expression of inflammatory (ILI $\beta, M M P-7$ and MMP-9) and innate immunity compo- 

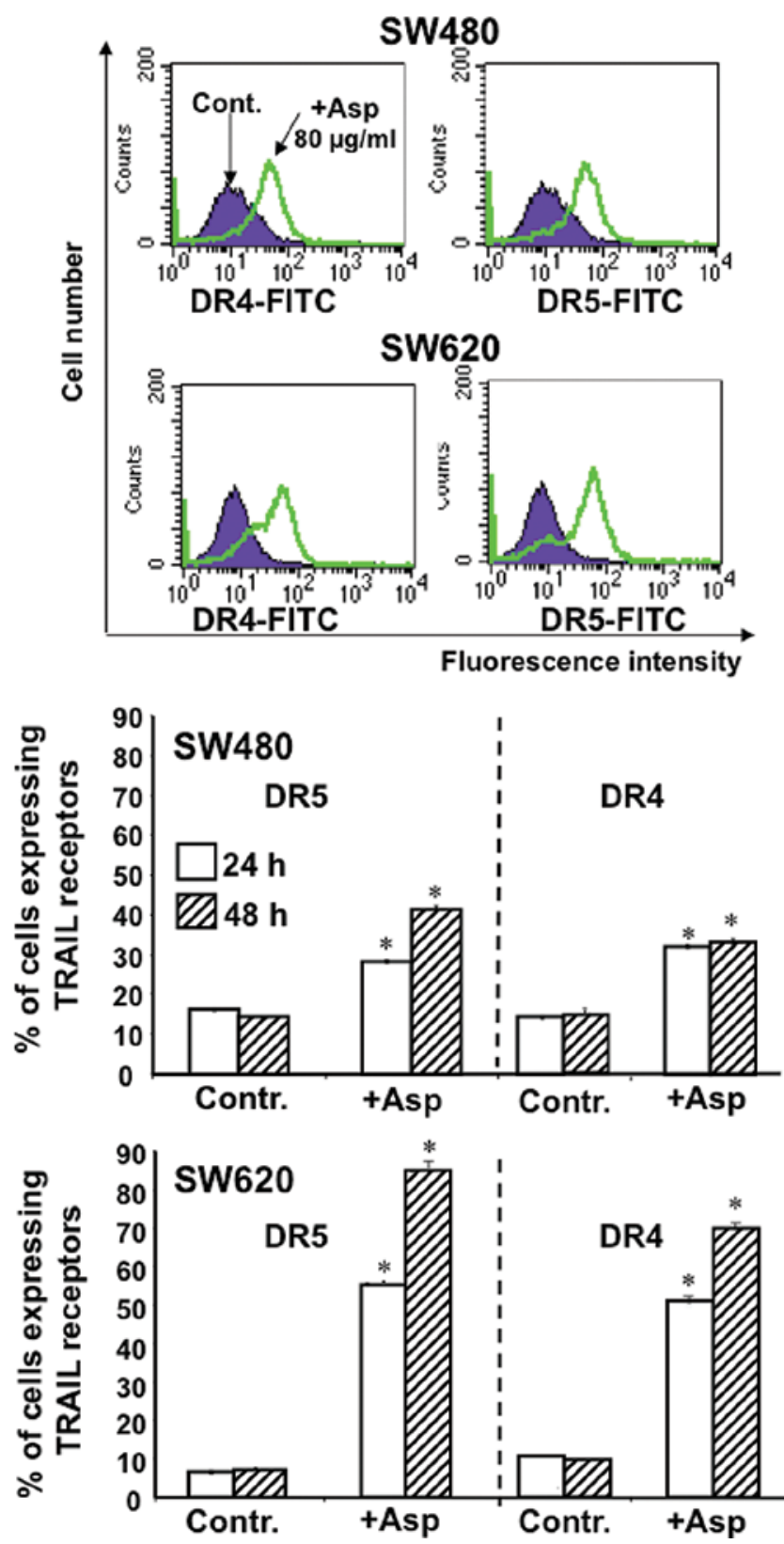

Figure 3. Activation of TRAIL-death receptors DR4 and DR5 by Asp. SW480 and SW620 cells were treated with Asp $(80 \mu \mathrm{g} / \mathrm{ml})$ for 24 and $48 \mathrm{~h}$. The expression of DR4 and DR5 receptors were analyzed by flow cytometry after staining with respective FITC-conjugated antibodies (details in Materials and methods). In the upper panel representative FACS histograms are shown, a shift to the right of fluorescence intensity (green line) corresponds to an increase of DR4 or DR5 receptor expression at the cell surface. In the lower panel data are presented as cytometer histogram plots representing the percentage of cells expressing DR4 or DR5 receptors. Data are the mean value \pm SE of three separate experiments. For each cell line and time period: Asp vs. controls, ${ }^{*} \mathrm{P}<0.05$.

nents $(D E F-5, L C N 2)$. In the colonic mucosa of AOM-injected rats treated with Asp, we found a significant downregulation of both MMP-7 and MMP-9, close to levels measured in the mucosa of the saline-injected rats (Fig. 8A). Moreover, the amount of $M M P-7$ transcript was directly correlated with the amount of MMP-7 protein (Fig. 8B). It was reported that the transcription of MMP genes is positively regulated by cytokines and growth factors such as interleukins (IL1 $\beta$ ) or TNF- $\alpha,(33,34)$ both suspected to be associated with
A

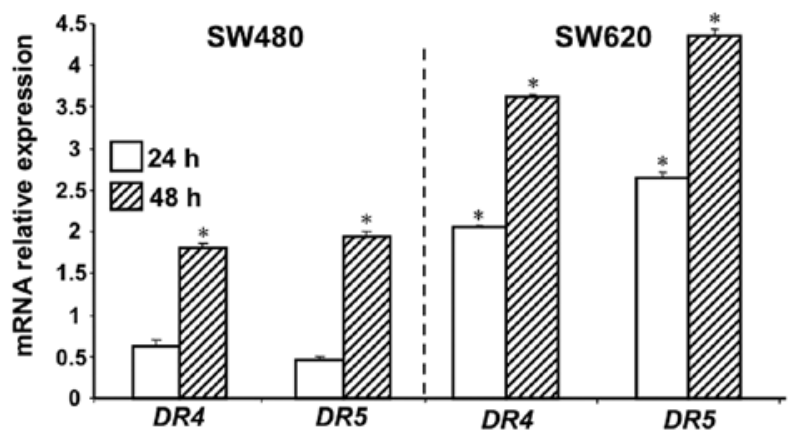

B

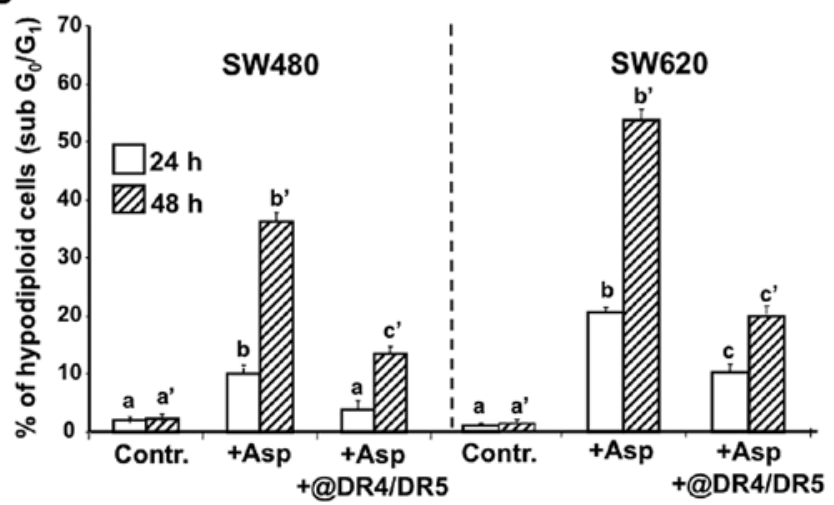

Figure 4. Involvement of TRAIL DR4/DR5 receptors in Asp-triggered cell death. SW480 and SW620 cells were treated with Asp ( $80 \mu \mathrm{g} / \mathrm{ml})$ for 24 and $48 \mathrm{~h}$. (A) Relative expression of DR4 and DR5 mRNA expression levels in SW480 and SW620 cells. Total RNA was isolated from controls and Asp-treated cells and qRT-PCR was performed in triplicate as detailed in Materials and methods. The mRNA level from control cells was used as an external reference and the level of $\beta$-actin mRNA was used as an internal reference to normalize the data. The mRNA fold-changes (mRNA relative expression) were expressed relative to the corresponding mRNA mean value found in control cells. Data are presented as the mean \pm SE. Asp vs. controls "P<0.01. (B) SW480 and SW620 cells were treated with Asp $(80 \mu \mathrm{g} / \mathrm{ml}) \pm \mathrm{DR} 4 / \mathrm{Fc}$ and DR5/Fc chimeric proteins (@DR4/DR5, 100 ng/ml) exhibiting a dominant-negative effect by blocking the endogenous receptors for 24 and $48 \mathrm{~h}$. SW480 and SW620 cells were then harvested and stained with propidium iodide for the measurement of hypodiploid bodies and analyzed by flow cytometry as detailed in Materials and methods. Data are the mean value $\pm \mathrm{SE}$ of at the least three separate experiments. For 24 or $48 \mathrm{~h}$, columns not sharing the same superscript letter differ significantly, $\mathrm{P}<0.05$.

the formation of colorectal adenoma in humans $(35,36)$. Accordingly, firstly we observed a significant upregulation of both $I L 1 \beta$ (more than 2-fold) and TNF- $\alpha$ (more than 4-fold) in the colonic mucosa of AOM-injected rats compared to the expression profiles of these genes in the colonic mucosa of saline-injected rats. Secondly, the treatment of AOM-injected rats with Asp inhibited the expression of these inflammatory cytokines close to the level measured in the mucosa of saline-injected rats (Fig. 8C).

We also found that two biomarkers of the innate immune system, $\alpha$-defensin-5 (DEF-5) and lipocalin-2 (LCN2), were upregulated at the mRNA level by 5 - and 11-fold, respectively, in the colon of Asp-treated AOM-injected rats compared to AOM-controls or saline-injected rats (Fig. 8D). Furthermore, the levels of the $L C N 2$ transcripts were correlated with an 
A
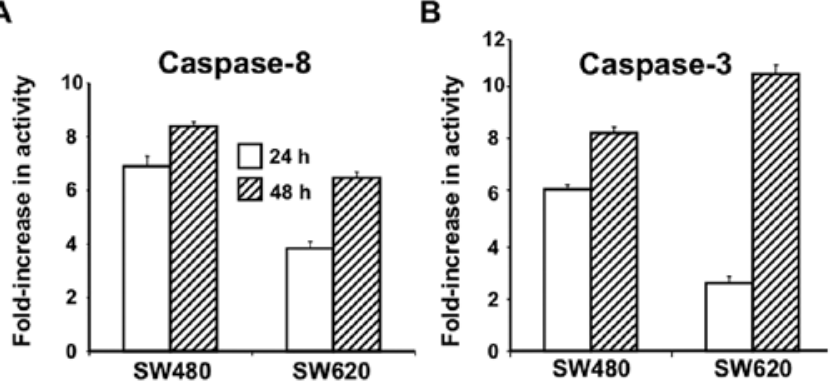

C

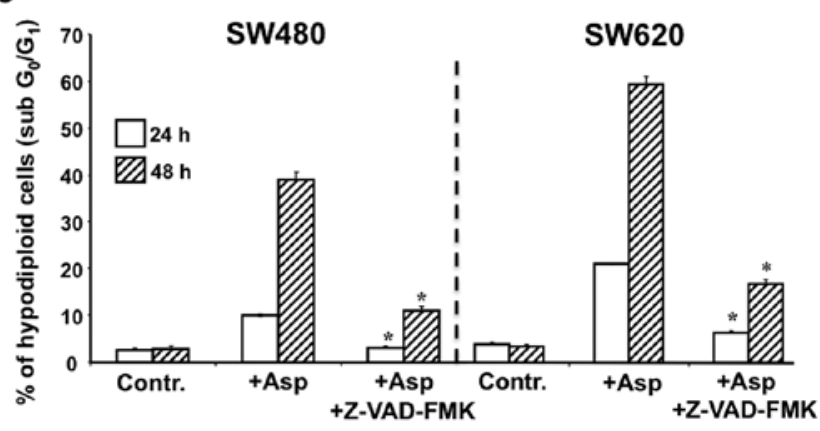

Figure 5. Effects of Asp treatment on caspase- 8 and caspase-3 activities. Cells were treated with Asp $(80 \mu \mathrm{g} / \mathrm{ml})$ for 24 and $48 \mathrm{~h}$. The measurement of caspase activities were performed by colorimetric method using specific substrates as described in Materials and methods. Data are indicated as nmol pNA released/mg of total protein. Fold increase in activity of (A) caspase-8 and (B) caspase-3 in SW480 and SW620 cells treated with Asp. Data are presented as the mean value $\pm \mathrm{SE}$ of at least three independent experiments. (C) Effect of caspase inhibition on Asp-induced cell death. SW480 and SW620 cells were pre-treated (for $1 \mathrm{~h} 30 \mathrm{~min}$ ) with the pan-caspase inhibitor Z-VAD-FMK and then treated with Asp $(80 \mu \mathrm{g} / \mathrm{ml})$ for 24 or $48 \mathrm{~h}$. Cells were then harvested and stained with propidium iodide for the measurement of hypodiploid bodies and analyzed by flow cytometry. For each cell line and time-period, Asp + caspase-inhibitor vs. Asp, ${ }^{*} \mathrm{P}<0.01$.

increased amount of $\mathrm{LCN} 2$ protein (Fig. 8B). These data were consistent with the reported negative correlation between the expression levels of host-defense genes and those implicated in the inflammatory response (37).

Asp activates apoptotic cell death in colonic mucosa. Since we observed that Asp exerted potent pro-apoptotic effects in human adenocarcinoma and metastatic cancer cells in vitro, we also investigated the effect of Asp on the expression of apoptotic molecules in the colonic mucosa of AOM-injected rats by RT-PCR quantitative analyses and western blot analysis.

Our data showed that Asp upregulated by 6-fold the level of TRAIL-death receptor DR5 and of TRAIL ligand (Fig. 9A) when compared to AOM or saline-injected rats. Furthermore, the levels of $D R 5$ and TRAIL transcripts were correlated with an increased amount of DR5 and TRAIL protein (Fig. 9B). Asp targeted specifically the TRAIL apoptotic signaling pathway since a treatment with Asp did not significantly modify the expression level of $F A S$, FAS ligand, Bax or Bcl-2.

In most cases, activation of the extrinsic TRAIL death receptor pathway leads to the activation of effector caspase-3. Accordingly, we found a 5-fold increase of caspase-3 activity

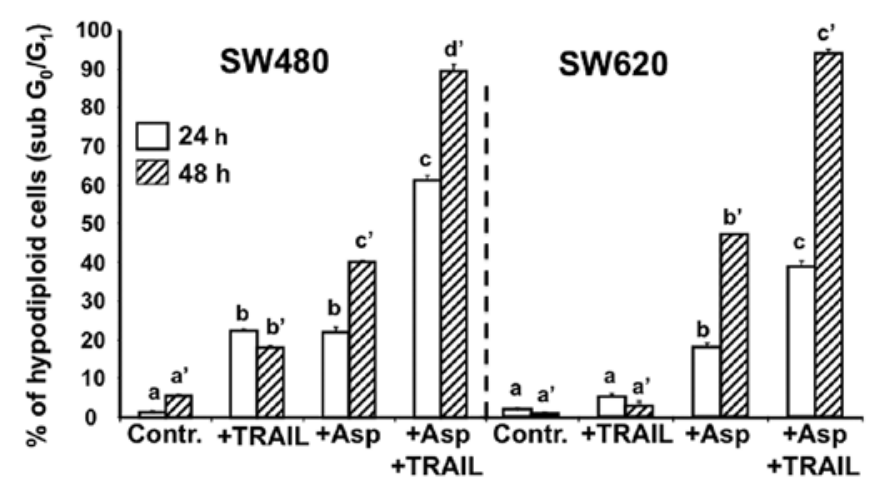

Figure 6. Effects of Asp and TRAIL combination on cell death. SW480 (TRAIL-sensitive) and SW620 (TRAIL-resistant) cells were treated with TRAIL $(50 \mathrm{ng} / \mathrm{ml})$ or Asp $(80 \mu \mathrm{g} / \mathrm{ml})$ or with a combination TRAIL + Asp for 24 or $48 \mathrm{~h}$. At each time point, cells were harvested and stained with propidium iodide and analysed by flow cytometry. The number of hypodiploid cells present in the subG0/G1 region is represented as histograms after 24 and $48 \mathrm{~h}$ of various treatments. For each cell line at 24 or $48 \mathrm{~h}$, columns not sharing the same superscript letter differ significantly $\mathrm{P}<0.05$.
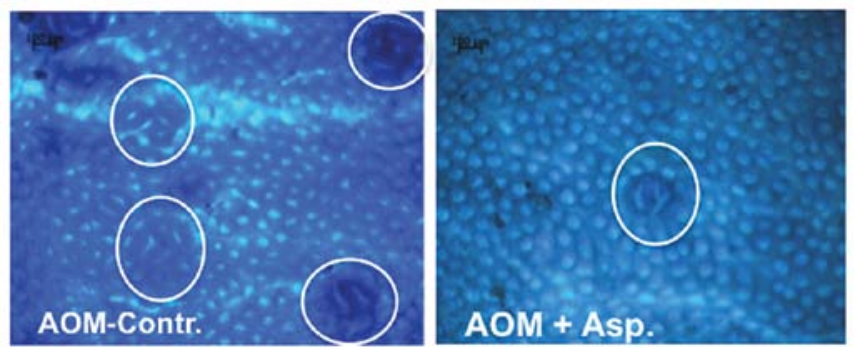

Total number of $\mathrm{ACF} / \mathrm{cm}$

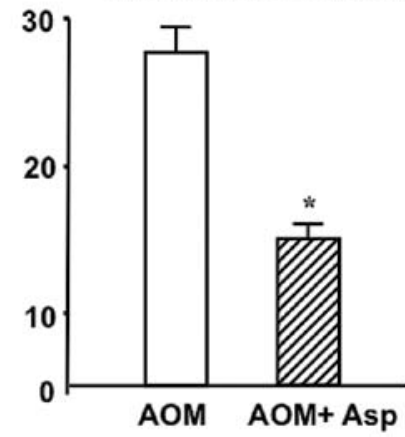

Figure 7. Chemopreventive effects of Asp administration in an experimental model of colon carcinogenesis. One week after the last injection of AOM (post-initiation), rats were randomly separated into two groups. One group $(\mathrm{n}=8)$ received daily a solution of $0.01 \% \mathrm{Asp}(14 \mathrm{mg} / \mathrm{kg}$ body weight) in drinking water. The AOM-control rats $(\mathrm{n}=8)$ received drinking water. The upper panel shows representative views of the distal colon mucosal surface with aberrant crypt foci (in circle). Lower panel shows the total number of aberrant crypt foci (per cm length) in the distal colon in AOM-injected control rats and in Asp treated AOM-injected rats. Data are presented as the mean $\pm \mathrm{SE},{ }^{*} \mathrm{P}<0.01$.

in the mucosa of Asp-treated AOM-Injected rats when compared to AOM-injected controls (Fig. 9C). These data are in accordance with in vitro data showing that Asp activated caspase-dependent apoptotic signaling pathway in human colon cancer SW480 and derived metastatic SW620 cells. 
A

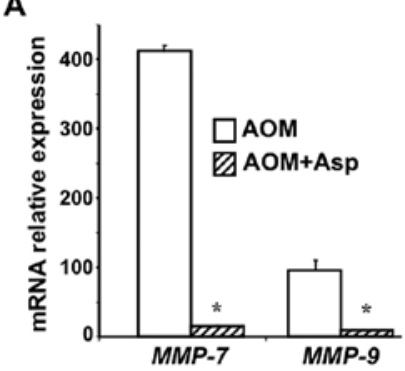

C

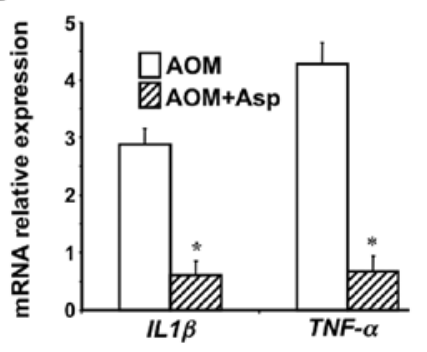

B
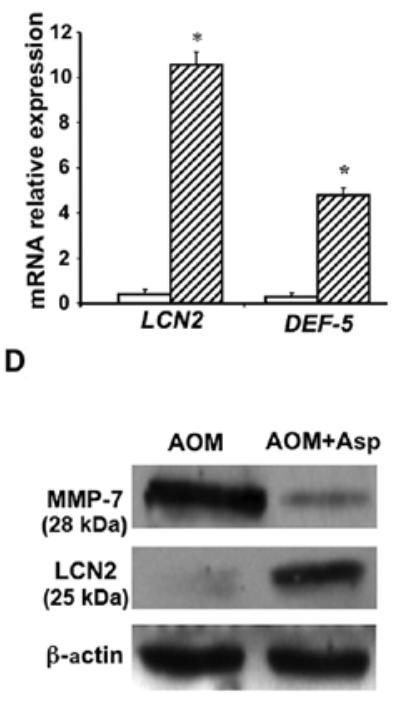

Figure 8. Effect of Asp treatment on the mRNA expression levels of (A) matrix metalloproteinase (MMP-7, MMP-9), (B) biomarkers of the innate immune system $(L C N 2, D E F-5)$ and (C) pro-inflammatory cytokines $(I L 1 \beta, T N F-\alpha)$ in the colonic mucosa of AOM-injected rats. Real-time PCR was performed in triplicate wells. The mRNA level from colonic mucosa of saline-injected control rats was used in all determinations as an external reference. The level of $\beta$-actin mRNA of each sample was used as an internal reference to normalize the data. The mRNA fold-changes (mRNA relative expression) were expressed relative to the corresponding mRNA mean value found in the colonic mucosa of saline injected rats $(n=8)$. Data are presented as the mean \pm SE, Asp treatment vs. control, ${ }^{*} \mathrm{P}<0.01$. (D) Western blot analysis of MMP-7 and LCN2 protein expression in the mucosal samples of AOM-injected control rats (AOM) and Asp-treated (+Asp) AOM-injected rats, $\beta$-actin was used as an internal control.

\section{Discussion}

Alterations of the processes controlling apoptosis extend the life span of cells and may favor cell neoplastic expansion independently of cell division (38). In addition, failure in apoptotic death contributes to resistance against host immune-based response and/or anticancer drug treatments. The expression of receptors belonging to the super family of tumor necrosis factor receptors such as TNF-related apoptosis inducing ligand (TRAIL) receptors DR4 and DR5, are often altered in patients with colon cancer (33). The ligand (TRAIL) by interacting with its apoptotic death receptors DR4 and DR5, selectively induces apoptosis in a wide variety of cancer cells (39). This finding has led to the development of anticancer strategies based on the use of TRAIL or TRAIL agonistic antibodies (40). However these strategies have shown only limited efficiency and the best treatment response to TRAIL agonist obtained in cancer patients from clinical studies is a stabilization of the disease (41). Nevertheless it seems that the sensitivity to TRAIL-induced apoptosis is a key factor influencing the efficacy of TRAIL treatment. Therefore, the TRAIL apoptotic pathway may be a valuable target with great potential for anticancer treatment when TRAIL or TRAIL agonists are used in combination with other anticancer therapies.

The search for dietary constituents with antitumor activity with high effectiveness on cancer cells and low

A

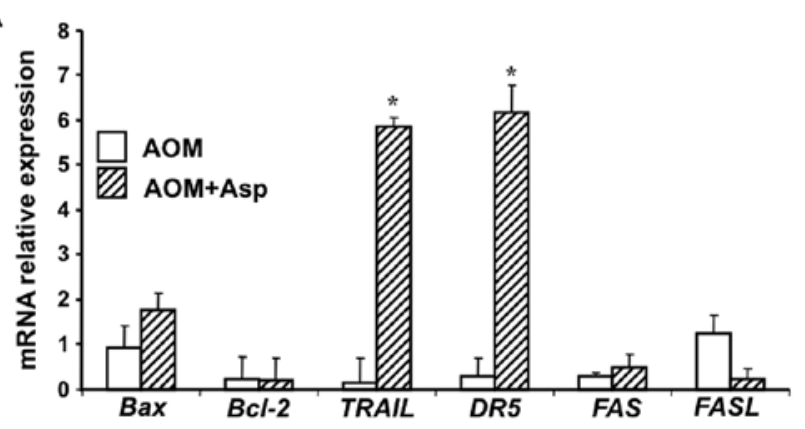

B

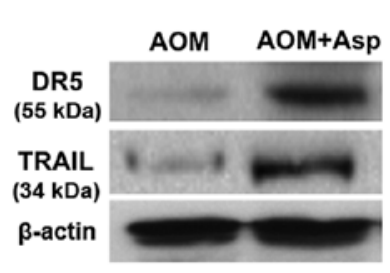

C

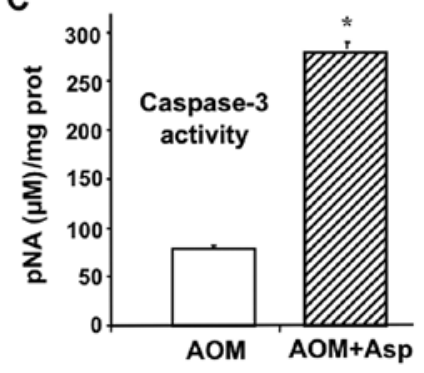

Figure 9. Asp activates apoptotic cell death in the colonic mucosa of AOM-injected rats. (A) Changes in the mRNA expression levels of various cell death biomarkers in the colonic mucosa of AOM-injected rats $(n=8)$ and Asp treated AOM-injected rats $(n=8)$. Real-time PCR was performed in triplicate wells. For further details see legend of Fig. 8. (B) Western blot analysis of the pro-apoptotic DR5 receptor and of TRAIL protein expression in the mucosal samples of AOM-injected control rats (AOM) and Asp-treated AOM-injected rats, $\beta$-actin was used as an internal control. (C) Caspase-3 activity in the colonic mucosal samples of AOM-injected control rats and Asp treated AOM-injected rats. For details see Materials and methods. Data are presented as the mean $\pm \mathrm{SE}$, Asp-treatment vs. control, ${ }^{*} \mathrm{P}<0.01$.

toxicity on normal tissues has become one of the hotspots in research on cancer prevention and treatment (42). Asparagus officinalis L. is a popular vegetable in Western and Oriental countries alike. Interestingly many components of asparagus are poorly absorbed when ingested, and a substantial amount remains intact in the digestive tract where it might exert protective effects targeting the colonic mucosa. In the present study we investigated the chemopreventive mechanisms of Asparagus officinalis $\mathrm{L}$. shoots extract (Asp), in vitro on human colon adenocarcinoma SW480 cells and their derived metastatic SW620 cells, and in vivo in a preclinical model of colon carcinogenesis in rat.

Here, we show that Asp-induced cancer cell death was mediated through the activation of the TRAIL apoptotic pathway in both adenocarcinoma SW480 cells and metastatic SW620 cells. In these cells Asp initiated a significant $(\mathrm{P}<0.01)$ upregulation of DR4 and DR5 transcripts and proteins. By inactivating the TRAIL death receptors with specific blocking agents (DR4/Fc and DR5/Fc) we were able to inhibit Asp-triggered cell death demonstrating the key role of TRAIL receptors in this process. It is noteworthy that Asp was able to induce the activity of both DR4 and DR5 death receptor in the metastatic SW620 cells which normally do not express active DR4/DR5 receptors at their cell surface and are known to be TRAIL-resistant $(43,44)$. Activation of DR4/DR5 by Asp led in both cell lines to the activation 
of caspase- 8 and caspase- 3 subsequently triggering the apoptotic cell death. This was attested by the fact that pancaspase-inhibitor Z-VAD-FMK inhibited the Asp-induced cell death in these two cell lines.

From these data it can be hypothesized that Asp-treatment might represent a way to sensitize resistant cancer cells to TRAIL-treatment via the activation of DR4/DR5 death receptors. This was confirmed by our present data showing that Asp was able to potentiate the effects of TRAIL on cell death, even in TRAIL-resistant metastatic cancer cells.

Based on our in vitro data demonstrating the potent proapoptotic effects of Asp, we have further aimed to evaluate its chemopreventive effects in a preclinical model of colon carcinogenesis. We show that $0.01 \%$ Asp freshly administered daily in drinking water ( $14 \mathrm{mg} / \mathrm{kg}$ body weight) to rats, for a duration of 7 weeks starting one week after injection with a chemical carcinogen (AOM), caused a 50\% reduction in the number of preneoplastic lesions (aberrant crypt foci) (ACF) at the surface of the colon. AOM-induced ACF have been widely used as a useful biomarker for colon carcinogenesis and for the evaluation of many chemopreventive agents $(23,24)$. In order to gain more insight into the molecular targets involved in the anti-neoplastic effects of Asp, the expression of several key genes and proteins involved in the inflammatory, immune and apoptotic responses were measured in the colonic mucosa.

It is widely reported that cytokines (IL1 $\beta, \mathrm{TNF}-\alpha$ ), matrix metalloproteinase (MMP-7, MMP-9) are involved in chronic inflammation, which creates a microenvironment favoring colon carcinogenesis (45). The role of these molecules have been linked to all steps involved in tumorigenesis, including initiation, cellular transformation, promotion, survival, invasion, and metastasis. Matrilysin (MMP-7) has been demonstrated to contribute to early stages of intestinal tumor progression (46). Chronic exposure to MMP-7 in premalignant epithelial cells can result in the selection of a subpopulation of cells that display a decreased sensitivity to pro-apoptotic signals. Additionally, such cells also demonstrate a significantly reduced sensitivity to drugs that stimulate apoptosis (46). Tissue inhibitors of MMPs have been suggested to be useful in combination therapy with TRAIL since it was reported that MMP inhibitors reduced tumor growth and angiogenesis in nude mice (47). Accordingly, our data indicate that $M M P-7$ and, to a lesser extent $M M P-9$, are significantly enhanced in colonic mucosa of AOM-injected rats and that their expression declined significantly $(\mathrm{P}<0.01)$ with Asp treatment. Furthermore, we observed that Asp drastically reduced $I L I \beta$ and TNF- $\alpha$ expression, which are known to induce an upregulation of MMPs $(48,49)$. Furthermore, we observed an inverse correlation between the genetic expression of these pro-inflammatory cytokines and that of host-defense components of the innate immune system such as $\alpha$-defensin-5 (DEF-5) and lipocalin 2 (LCN2), these genes being upregulated in Asp-treated AOM rats. Bioactive asparagus constituents such as saponins or fructooligosaccharides are well recognized as potent immune stimulators $(50,51)$. These effects might be in part modulated by DEF-5 and LCN2 $(38,52)$, which are considered as active weapons against several cancer cell types (53). Furthermore, an impaired expression of DEF-5 and LCN2 and the over- production of the pro-inflammatory cytokine IL1 $\beta$ have been closely associated with inflammatory bowel disease (54-56). It was also shown that DEF-5 plays an important role in the maintenance of intestinal immune homeostasis by controlling the production of IL1 $\beta$ (57).

Progressive inhibition of apoptosis has been described during transformation of colorectal epithelium to carcinoma. Here we showed in accordance with our in vitro findings that Asp-treatment of AOM-injected rats induced an important upregulation of biomarkers of the TRAIL-apoptotic pathway like DR5 and TRAIL at both gene and protein levels. These effects were also associated with an activation of caspase-3 in the colonic mucosa of Asp-treated AOM-rats.

In conclusion, this study demonstrates that a methanolic extract of white asparagus shoots activates the TRAIL death receptor pathway in the SW480 human colon adenocarcinoma cells and in their derived TRAIL-resistant metastatic SW620 cells. This extract also sensitized these cells to TRAIL-induced apoptosis via the upregulation of death receptors (DR4/DR5) and the associated activation of caspase- 8 and caspase-3, finally leading to cell death. We also demonstrated that asparagus extract administered in drinking water to AOM-injected rats exerted various anti-carcinogenic and protective effects on the colonic mucosa at early post-initiation stages. At the molecular level, the asparagus extract exhibited multi-targeted effects on the preneoplastic colonic mucosa including the inhibition of cellular pro-inflammatory mediators such as IL1 $\beta, \mathrm{TNF}-\alpha$, MMP-7 and MMP-9, in association with an increased expression of the host-defense mediators $\alpha$-defensin- 5 and lipocalin 2. In the colonic mucosa of AOM-injected rats receiving the asparagus extract we confirmed the pro-apoptotic effects observed in vitro involving the activation of the TRAIL death receptor signaling pathway. Taken together our data highlight the chemopreventive potential of asparagus shoot extract on colon carcinogenesis and its ability to promote normal cellular homeostasis.

\section{Acknowledgements}

This research was part of the 'nutrhi.net' project co-financed by the European Regional Development Fund: Interreg IV Oberrhein/Rhin Supérieur.

\section{References}

1. Kelloff GJ, Boone CW, Crowell JA, Steele VE, Lubet R and Sigman CC: Chemopreventive drug development: perspectives and progress. Cancer Epidemiol Biomarkers Prev 3: 85-98, 1994.

2. Kelloff GJ, Boone CW, Crowell JA, Steele VE, Luber RA, Doody LA, Malone WF, Hawk ET and Sigman CC: New agents for cancer chemoprevention. J Cell Biochem (Suppl) 26: 1-28, 1996.

3. Corpet DE and Taché S: Most effective colon cancer chemopreventive agents in rats: a systematic review of aberrant crypt foci and tumor data, ranked by potency. Nutr Cancer 43: 1-21, 2002.

4. Tanaka T and Sugie S: Inhibition of colon carcinogenesis by dietary non-nutritive compounds. J Toxicol Pathol 20: 215-235, 2007.

5. Kushi LH, Meyer KA and Jacobs DR Jr: Cereals, legumes, and chronic disease risk reduction: evidence from epidemiologic studies. Am J Clin Nutr 70: 451S-458S, 1999. 
6. Bobe G, Barrett KG, Mentor-Marcel RA, Saffiotti U, Young MR, Colburn NH, Albert PS, Bennink MR and Lanza E: Dietary cooked navy beans and their fractions attenuate colon carcinogenesis in azoxymethane-induced ob/ob mice. Nutr Cancer 60 373-381, 2008.

7. Steele VE, Pereira MA, Sigman CC and Kelloff GJ: Cancer chemoprevention agent development strategies for genistein. J Nutr 125: 713S-716S, 1995.

8. Yu S, Poobsasert O, Kennelly EJ, Chin CK, Ho CT, Huang MT, Garrison SA and Cordell GA: Steroidal saponins from Asparagus officinalis and their cytotoxic activity. Planta Medica 63: 258-262, 1997 .

9. Huang $X$ and Kong L: Steroidal saponins from roots of Asparagus officinalis. Steroids 71: 171-176, 2006.

10. Shao Y, Chin CK, Ho CT, Ma W, Garrison SA and Huang MT: Anti-tumor activity of the crude saponins obtained from asparagus. Cancer Lett 104: 31-36, 1996.

11. Wang M, Tadmor Y, Wu QL, Chin CK, Garrison SA and Simon JE: Quantification of protodioscin and rutin in asparagus shoots by LC/MS and HPLC methods. J Agric Food Chem 51: 6132-6136, 2003

12. Makris DP and Rossiter JT: Domestic processing of onion bulbs (Allium cepa) and asparagus spears (Asparagus officinalis): effect on flavonol content and antioxidant status. J Agric Food Chem 49: 3216-3222, 2001

13. Villanueva-Suarez MJ, Redondo-Cuenca A, RodriguezSevilla MD and Heredia-Moreno A: Postharvest storage of white asparagus (Asparagus officinalis $\mathrm{I}$.): changes in dietary fiber (Nonstarch polysaccharides). J Agric Food Chem 47: 3832-3836, 1999.

14. Yamamori A, Onodera S, Kikuchi M and Shiomi N: Two novel oligosaccharides formed by $1 \mathrm{~F}$-fructosyltransferase purified from roots of asparagus (Asparagus officinalis L.). Biosci Biotechnol Biochem 66: 1419-1422, 2002.

15. Rodriguez R, Jaramillo S, Rodriguez G, Espejo JA, Guillén R, Fernandez-Bolanos J, Heredia A and Jiménez A: Antioxidant activity of ethanolic extracts from several asparagus cultivars J Agric Food Chem 53: 5212-5217, 2005.

16. Jang DS, Cuendet M, Fong HH, Pezzuto JM and Kinghorn AD: Constituents of Asparagus officinalis evaluated for inhibitory activity against cyclooxygenase-2. J Agric Food Chem 52: 2218-2222, 2004.

17. Mei HS, Wu YQMG and Wu ZY: The effects by eating asparagus spears on blood-lipid levels of human body. Acta Sci Nat Univ Pekin 26: 369-372 1990.

18. Wang $\mathrm{H}$ and $\mathrm{Ng} \mathrm{TB}$ : Isolation of a novel deoxyribonuclease with antifungal activity from Asparagus officinalis seeds. Biochem Biophys Res Commun 289: 120-124, 2001.

19. Huang J, Sun Y and Lu S: Experimental study on apoptosis induced by ursolic acid isolated from asparagus in HL-60 cells. Zhongguo Zhong Xi Yi Jie He Za Zhi 19: 296-298, 1999 (In Chinese).

20. Liu W, Huang XF, Qi Q, Dai QS, Yang L, Nie FF, Lu N, Gong DD, Kong LY and Guo QL: Asparanin A induces G(2)/M cell cycle arrest and apoptosis in human hepatocellular carcinoma HepG2 cells. Biochem Biophys Res Commun 381: 700-705, 2009.

21. Bhutani KK, Paul AT, Fayad W and Linder S: Apoptosis inducing activity of steroidal constituents from Solanum xanthocarpum and Asparagus racemosus. Phytomedicine 17 789-793, 2010

22. Hewitt RE, McMarlin A, Kleiner D, Wersto R, Martin P, Tsokos M, Stamp GW and Stetler-Stevenson WG: Validation of a model of colon cancer progression. J Pathol 192: 446-454 2000

23. Reddy BS: Studies with azoxymethane-rat preclinical model for assessing colon tumor development and chemoprevention. Environ Mol Mutagen 44: 26-35, 2004.

24. Corpet DE and Pierre F: How good are rodent models of carcinogenesis in predicting efficacy in humans? A systematic review and meta-analysis of colon cancer chemoprevention in rats, mice and humans. Eur J Cancer 41: 1911-1922, 2005.

25. Bousserouel S, Gossé F, Bouhadjar M, Soler L, Marescaux J and Raul F: Long-term administration of aspirin inhibits tumour formation and triggers anti-neoplastic molecular changes in a pre-clinical model of colon carcinogenesis. Oncol Rep 23 . 511-517, 2010.

26. Pereira MA, Barnes LH, Rassman VL, Kelloff GV and Steele VE: Use of azoxymethane-induced foci of aberrant crypts in rat colon to identify potential cancer chemopreventive agents. Carcinogenesis 15: 1049-1054, 1994.
27. Takayama T, Katsuki S, Takahashi Y, Ohi M, Nojiri S, Sakamaki S, Kogawa K, Miyake H and Niitsu Y: Aberrant crypt foci of the colon as precursors of adenoma and cancer. N Engl J Med 339: 1277-1284, 1998

28. Bird RP and Good CK: The significance of aberrant crypt foci in understanding the pathogenesis of colon cancer. Toxicol Lett 112-113: 395-402, 2000.

29. Livak KJ and Schmittgen TD: Analysis of relative gene expression data using real-time quantitative PCR and the 2(-Delta Delta C(T)) method. Methods 25: 402-408, 2001

30. Riccardi C and Nicoletti I: Analysis of apoptosis by propidium iodide staining and flow cytometry. Nat Protoc 1: 1458-1461, 2006.

31. Reed JC: Mechanisms of apoptosis. Am J Pathol 157: 1415-1430, 2000.

32. Jin Z, McDonald ER III, Dicker DT and El-Deiry WS: Deficient tumor necrosis factor-related apoptosis-inducing ligand (TRAIL) death receptor transport to the cell surface in human colon cancer cells selected for resistance to TRAIL-induced apoptosis. J Biol Chem 279: 35829-35839, 2004.

33. Cawston TE and Wilson AJ: Understanding the role of tissue degrading enzymes and their inhibitors in development and disease. Best Pract Res Clin Rheumatol 20: 983-1002, 2006.

34. Spinale FG: Myocardial matrix remodeling and the matrix metalloproteinases: Influence on cardiac form and function. Physiol Rev 87: 1285-1342, 2007.

35. Gunter MJ, Canzian F, Landi S, Chanock SJ, Sinha R and Rothman N: Inflammation-related gene polymorphisms and colorectal adenoma. Cancer Epidemiol Biomarkers Prev 15: 1126-1131, 2006

36. Buck I, Morceau F, Grigorakaki C, Dicato M and Diederich M: Linking anemia to inflammation and cancer: the crucial role of TNFalpha. Biochem Pharmacol 77: 1572-1579, 2009.

37. Ramasundara M, Leach ST, Lemberg DA and Day AS: Defensins and inflammation: the role of defensins in inflammatory bowel disease. J Gastroenterol Hepatol 24: 202-208, 2009.

38. Reed JC: Dysregulation of apoptosis in cancer. J Clin Oncol 17: 2941-2953, 1999.

39. Wang S: TRAIL: a sword for killing tumors. Curr Med Chem 17: 3309-3317, 2010

40. Bellail AC, Qi L, Mulligan P, Chhabra V and Hao C: TRAIL agonists on clinical trials for cancer therapy: the promises and the challenges. Rev Recent Clin Trials 4: 34-41, 2009.

41. Thorburn A, Behbakht K and Ford H: Trail receptor-targeted therapeutics: resistance mechanisms and strategies to avoid them. Drug Resist Updat 11: 17-24, 2008.

42. Wang H, Khor TO, Shu L, Su Z, Fuentes F, Lee JH and Kong AN: Plants vs. cancer: a review on natural phytochemicals in preventing and treating cancers and their drug ability. Anticancer Agents Med Chem 12: 1281-1305, 2012.

43. Kong CK, Lam WS, Chiu LC, Ooi VE, Sun SS and Wong YS: A rice bran polyphenol, cycloartenyl ferulate, elicits apoptosis in human colorectal adenocarcinoma SW480 and sensitizes metastatic SW620 cells to TRAIL-induced apoptosis. Biochem Pharmacol 77: 1487-1496, 2009.

44. Kauntz H, Bousserouel S, Gossé F and Raul F: The flavonolignan silibinin potentiates TRAIL-induced apoptosis in human colon adenocarcinoma and in derived TRAIL-resistant metastatic cells. Apoptosis 17: 797-809, 2012.

45. Lu H, Ouyang W and Huang C: Inflammation, a key event in cancer development. Mol Cancer Res 4: 221-233, 2006.

46. Fingleton B, Vargo-Gogola T, Crawford HC and Matrisian LM: Matrilysin (MMP-7) expression selects for cells with reduced sensitivity to apoptosis. Neoplasia 3: 459-468, 2001.

47. Nyormoi O, Mills L and Bar-Eli M: An MMP-2/MMP-9 inhibitor, 5a, enhances apoptosis induced by ligands of the TNF receptor superfamily in cancer cells. Cell Death Differ 10: $558-569,2003$

48. Friedl $\mathrm{P}$ and Wolf $\mathrm{K}$ : Tumor-cell invasion and migration: Diversity and escape mechanisms. Nat Rev Cancer 3: 362-374, 2003.

49. Johansson N, Ahonen M and Kähäri VM: Matrix metalloproteinases in tumor invasion. Cell Mol Life Sci 57: 5-15, 2000.

50. Rajput ZI, Hu SH, Xiao CW and Arijo AG: Adjuvant effects of saponins on animal immune responses. J Zhejiang Univ Sci B 8: 153-161, 2007.

51. Sabater-Molina M, Larqué E, Torrella F and Zamora S: Dietary fructooligosaccharides and potential benefits on health. J Physiol Biochem 65: 215-328, 2009. 
52. Chien MH, Ying TH, Yang SF, Yu JK, Hsu CW, Hsieh SC and Hsieh YH: Lipocalin-2 induces apoptosis in human hepatocellular carcinoma cells through activation of mitochondria pathways. Cell Biochem Biophys 64: 177-186, 2012.

53. Papo N and Shai Y: Host defense peptides as new weapons in cancer treatment. Cell Mol Life Sci 62: 784-790, 2005.

54. Lee HJ, Lee EK, Lee KJ, Hong SW, Yoon Y and Kim JS: Ectopic expression of neutrophil gelatinase-associated lipocalin suppresses the invasion and liver metastasis of colon cancer cells. Int J Cancer 118: 2490-2497, 2006.

55. Simms LA, Doecke JD, Walsh MD, Huang N, Fowler EV and Radford-Smith GL: Reduced alpha-defensin expression is associated with inflammation and not NOD2 mutation status in ileal Crohn's disease. Gut 57: 903-910, 2008.
56. Friedl A, Stoesz SP, Buckley P and Gould MN: Neutrophil gelatinase-associated lipocalin in normal and neoplastic human tissues. Cell type-specific pattern of expression. Histochem J 31: 433-441, 1999.

57. Shi J, Aono S, Lu W, Ouellette AJ, Hu X, Ji Y, Wang L, Lenz S, van Ginkel FW, Liles M, Dykstra C, Morrison EE and Elson CO: A novel role for defensins in intestinal homeostasis: regulation of IL-1beta secretion. J Immunol 179: 1245-1253, 2007. 